\title{
Dominant Influence of the Terminal Molecule of PNIPA Chain on Wettability
}

(Pengaruh Dominan Molekul Terminal Raintaian PNIPA ke atas Kebolehbasahan)

\author{
NURUL HUDA*, MOHD. RASHID \& NAHIDA SULTANA
}

\begin{abstract}
Poly(N-isopropylacrylamide) (PNIPA) brushes on silicon substrate was constructed and molecular weight and polydispersity index was controlled precisely. Molecular behavior of the PNIPA grafted surface was observed by using captive bubble contact angle method. A very interesting phenomenon of high density PNIPA grafted membrane with a chloride terminal molecule was observed. The contact angle of high density PNIPA-Cl increased sharply while the temperature rises above $32^{\circ} \mathrm{C}$. But in the case of PNIPA gel surface the contact angle result decreases sharply while the temperature reaches above lower critical solution temperature (LCST). In order to identify the reason behind this abnormal behavior of PNIPA-Cl grafted membrane, the terminal chloride molecule of PNIPA chain was modified to less electronegative azide (-N $\left.N_{3}\right)$ as well as carboxylic acid (-COOH). Finally it was found that terminal molecule of high density PNIPA grafted membrane has a great influences on the wettability change of PNIPA membrane in water by changing the temperature.
\end{abstract}

Keywords: ATRP; grafted membrane; monomer; PNIPA

ABSTRAK

Berus poli(N-isopropilakrilamida) (PNIPA) pada substrat silikon telah dibina dan berat molekul serta indeks kepoliserakan telah dikawal dengan tepat. Tingkah laku molekul permukaan cantuman PNIPA telah diperhatikan dengan menggunakan kaedah sudut sentuhan tangkapan gelembung. Suatu fenomena yang sangat menarik untuk membran cantuman PNIPA ketumpatan tinggi dengan klorida terminal molekul diperhatikan. Sudut sentuh PNIPA-Cl ketumpatan tinggi meningkat dengan ketara manakala suhu meningkat melebihi $32^{\circ}$ C. Tetapi dalam kes gel permukaan PNIPA, keputusan sudut sentuh berkurangan secara mendadak semasa suhu mencapai tahap di atas suhu kritikal larutan (LCST). Untuk mengenal pasti sebab di sebalik tingkah laku tidak normal daripada PNIPA-Cl membran cantuman ini, molekul klorida terminal rantaian PNIPA diubah suai untuk mengurangkan azida elektronegatif (- $\left.N_{3}\right)$ serta asid karbosilik (-COOH). Kesimpulannya, didapati bahawa molekul terminal ketumpatan tinggi PNIPA membran cantuman mempunyai pengaruh yang besar pada perubahan kebolehbasahan membran PNIPA dalam air dengan mengubah suhunya.

Kata kunci: ATRP; grafted membran; monomer; PNIPA

\section{INTRODUCTION}

Temperature responsive polymers have an appropriate meaning to define switchable surface properties when grafted on solid surfaces. This is because; they can easily alter the conformation of grafted polymer by changing temperature (Manias et al. 2005). These surface properties can also reveal to more complex phenomena, such as controlled movement of small particles on polymer-bearing surfaces; topography and adhesion facilitating movement including surface patterning and protective coating (Grundke et al. 2015; Prokhorova et al. 2003). This surface has its tunable properties in response to environmental changes such as temperature, $\mathrm{pH}$, wettability, adhesion, topography and humidity. Surface-initiated polymerization attached with atom transfer radical polymerization (ATRP) is one of the most well controlled living radical polymerization. It has been recognized as a versatile method for generating ultrathin film of surface grafted polymer brushes with well defined thickness and architecture. An example of this type of smart material is a Poly( $N$-isopropylacrylamide) (PNIPA), which has a lower critical solution temperature at $\sim 32^{\circ} \mathrm{C}$ in water, between room temperature and physiological temperature (Chen \& Hoffman 1995). Below the LCST, water is a good solvent and the PNIPA is hydrated and follow a random coil conformation. But water acts as a poor solvent and the PNIPA is dehydrated and collapsed into a globular conformation at above LCST (Chen \& Hoffman 1995). If grafting density of polymer chains on solid surface is adequately high, polymer chains are constrain to stretch away from the surface to avoid overlap. This arrangement of polymer solution is called as 'Polymer brushes' (Lamson et al. 2016). Such structure of polymer brushes is technologically important and is a matter of much scientific interest.

Contact angle measurement is one of the efficient ways to investigate macroscopic properties of a given polymer brush and is governed by both the chemical 
composition and the geometrical microstructure of the surface. During measuring the contact angle underneath PNIPA grafted membrane, air bubble is attached with the surface of the polymer membrane by adhesive force. At the beginning of the adhesion process, an adhesive is essential to be in a liquid state to form a deep contact with the solid surface. Therefore, wetting is usually the first stage in adhesion (Abraham 2004). In the case of adhesion in an aqueous environment, the liquid acts as an aqueous solution whereas the fluid stimulates the adhesive. Wetting on the rough surface may consider either of two regimes: homogenous wetting (Wenzel 1936) or heterogeneous wetting (Cassie \& Baxter 1944). In homogeneous wetting, liquid completely penetrates into the rough grooves, whereas air is trapped underneath the liquid, inside the rough groves at heterogeneous wetting. The transition between these regimes plays an important role in the hydrophilicity and hydrophobicity (Pawel et al. 2016).

It is well known that many polymer brushes on solid surfaces composed by different monomers undergo a volume phase transition from hydrophobic state to hydrophilic state in response to infinitesimal changes in temperature, $\mathrm{pH}$, solvent composition and hydrostatic pressure (Jin et al. 2014). The volume phase transition is very important because of its technological importance for applications to actuators and drug delivery system (Okano 1993). Up to now, many investigations have been carried out to examine the phase transition of PNIPA as a function of temperature, $\mathrm{pH}$ or hydrostatic pressure (Kari \&Yoram 2014). But the phase transition of polymer brash, considering the hydrophilic and hydrophobic properties, no systematic study about the mechanism or reason has been reported.

High-density polymer brushes of PNIPA on silicon surface by the 'grafting from' method was synthesized and static contact angle of sessile air bubbles in water on PNIPA grafted membrane surfaces was measured by our group (Hiromasa et al. 2010). Therefore, we observed that PNIPA membrane showed an unexpected phase transition behavior at temperature near LCST. The contact angle of air bubble underneath the high-density polymer brush gradually decreases up to around $25^{\circ} \mathrm{C}$ in water; however, the value of the contact angle starts to increase dramatically from around the LCST of free PNIPA in water and becomes constant over $40^{\circ} \mathrm{C}$. This type of behavior shown by PNIPA grafted membrane does not follow the contact angle result of usually observed PNIPA gel surface (Atsushi \& Yasuhiro 1999). In order to find out the reason behind this surprising behavior, we converted the terminal Chlorine molecule of the PNIPA grafted chain by electronegative Azide group and checked the wettability. Then the electronegative Azide molecule of PNIPA chain was also converted to more hydrophilic carboxyl acid group and observed the effect of terminal end molecule of the PNIPA brush on the wettability. The phase transition behavior of PNIPA grafted membranes under different $\mathrm{pH}$ solutions was also observed.

\section{MATERIALS}

Tetrahydrofuran (THF) (Kishida Chemical Co. Ltd.) and di-methylformaldehyde (DMF) (Kishida Chemical Co, Ltd.) were distilled from calcium hydride. Sodium Azide $\left(\mathrm{NaN}_{3}\right)(99.9 \%)$ (Sigma Aldrich) and 4-ethanoic benzoic acid (99.5\%) (AB Chem. Inc.) were used as received. Deuterated solvents, dimethylsulfoxide- $d_{6}(d$-DMSO) and deuterium oxide $\left(\mathrm{D}_{2} \mathrm{O}\right)$, for ${ }^{1} \mathrm{H}$ NMR and FT-IR analyses, were used as received. Water was purified using a Direct-Q UV water purification system (Millipore Corp.) and used in all experiments. All other chemicals used in this study were purchased at the highest purity and used as received. A silicon wafer with a crystalline orientation of 100 and one polished side was purchased from Toshiba Semiconductor Company.

GENERAL PROCEDURE FOR SYNTHESIS OF GRAFTED PNIPA FROM ATRP INITIATOR-MODIFIED SILICON WAFERS

The best approach to the synthesis of a well-defined high-density brush is the grafting from method' using a surface bound initiator (Yamamoto et al. 2000). ATRP is attractive because it can provide good control over polymer molecular weight, PDI and end groups. The appropriate selection of reaction parameter, such as initiators, catalysts, solvents and temperatures for ATRP, results in polymers with high conversions, low PDIs and defined average polymer molecular weights. Catalyst inactivation, low values of ATRP equilibrium constants and displacement of the terminal halide has been recognized as complicating factors during polymerization. The combination of a chloropropionate functionalized initiator and $\mathrm{Me}_{6}$ TREN as the ligand was found to be a good system for the ATRP of acrylamide derivatives. Consequently, using alkyl chlorides rather than bromides as initiators in conjunction with $\mathrm{Me}_{6}$ TREN as a ligand improve polymer conversion rate. Moreover, DMSO was chosen as the solvent for ATRP of NIPA on the premise that a solvent with the electron-pair donating property could interact with the amide groups of NIPA. In addition, DMSO is a good solvent for PNIPA over a very wide range of temperatures. The successful synthesis of the ATRP of NIPA in pure water has been reported recently, but we did not choose the water reaction system because of the high sensitivity of the PNIPA. Thus, we used CPU-dMCS as a surface-modified initiator, $\mathrm{CuCl} / \mathrm{Me}_{6}$ TREN as a catalytic system and DMSO as a solvent. ECP was added as a free initiator in the reaction solution to control the polymerization process. Without using the free initiator, the concentration of $\mathrm{Cu}^{\mathrm{II}}$ complex produced from the reaction at the surface becomes too low to deactivate the active chain ends of polymers with a sufficiently high rate. The concentration of $\mathrm{Cu}^{\mathrm{II}}$ complex can increase automatically and adjusted by adding the free initiator. Furthermore, information about the polymerization product, such as the average polymer molecular weight and PDI in the brush can be observed by observing those of the free polymer because good agreement in the number-average molecular weight 
$\left(\mathrm{M}_{\mathrm{n}}\right)$ and PDI between the graft and free polymers has been confirmed by several research groups.

In a typical experiment ([NIPA]:[ECP]:[CuCl]:[ $\mathrm{Me}_{6}{ }_{6}$ REN $]$ $=1000: 1: 1: 1)$, a $10 \mathrm{~mL}$ stoppered test tube was filled with NIPA (3.39 g, $30 \mathrm{mmol})$ and $3.40 \mathrm{~g}$ of DMSO as the solvent. The solution was sealed with a three-way stopcock and cycled three times between argon gas and a vacuum to remove the oxygen. ECP $(4.1 \mathrm{mg}, 0.03 \mathrm{mmol})$ as a free initiator, $\mathrm{CuCl}(3.0 \mathrm{mg}, 0.03 \mathrm{mmol})$ with $\mathrm{Me}_{6}$ TREN (6.9 $\mathrm{mg}, 0.03 \mathrm{mmol}$ ) as a catalyst and the initiator-modified silicon wafer were then added to the solution in a glovebox. The sealed test tube was placed into a water bath with a temperature of $20^{\circ} \mathrm{C}$, to occur polymerization. A small amount of hydroquinone was added to the test tube to stop the polymerization after a preplanned time. The newly formed polymer grafted membrane was washed with ethanol with sonication for $1 \mathrm{~min}$ and rinsed with the EDTA solution, distilled water, ethanol to remove unreacted species, the catalyst and free polymers and dried under a $\mathrm{N}_{2}$ stream. The resultant polymer solution was used to determine the monomer conversion by ${ }^{1} \mathrm{H}$ NMR in DMSO-d and to examine the average polymer molecular weight and polydispersity index (PDI) by gel permeation chromatography (GPC). Figure 1 shows the GPC data of PNIPA-Cl polymer with $\mathrm{M}_{\mathrm{n}}=11225, \mathrm{M}_{\mathrm{w}} / \mathrm{M}_{\mathrm{n}}=1.14$.

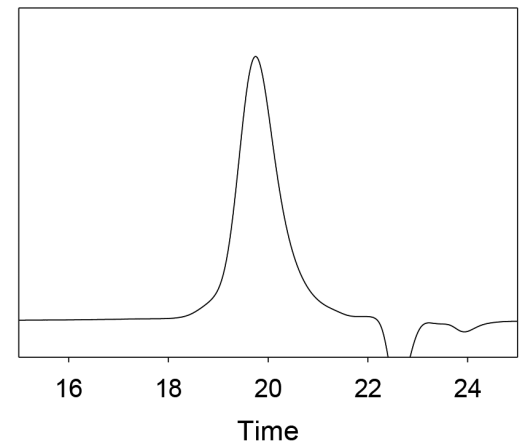

FIGURE 1. GPC chart of PNIPA-Cl with $\mathrm{Mn}=11225, \mathrm{Mw} / \mathrm{Mn}=1.14$

\section{SYNTHESIS OF PNIPA-N}

Synthesis procedure of PNIPA-Cl was briefly described elsewhere (Hiromasa et al. 2010) and was confirmed by ${ }^{1} \mathrm{H}$ NMR data (Figure 2). PNIPA-Cl ( $\left.8.5 \mathrm{~g}\right)$, DMF $(30 \mathrm{~mL})$ and $\mathrm{NaN}_{3}$ (325 mg, $5 \mathrm{mmol}$ ) were added in a $50 \mathrm{~mL}$ roundbottom flask. The reaction mixture was allowed to stir at $45^{\circ} \mathrm{C}$ for $48 \mathrm{~h}$. Then the DMF was removed at reduced pressure and the remaining portion was diluted with THF. The concentrated solution was precipitated into an excess of anhydrous hexane. The sediments were re-dissolved in THF and passed through a neutral alumina column to remove the residual sodium salts. The obtained product was dried overnight in a vacuum dryer for $24 \mathrm{~h}$ (yield: $\left.85 \%, M_{n}=7400, M_{w} / M_{n}=1.12\right)$. Successful synthesis of PNIPA-N $\mathrm{N}_{3}$ was confirmed by the azide signal obtained at 2100 wavenumber $/ \mathrm{cm}^{-1}$ from the FT-IR spectra (Figure 3 ).

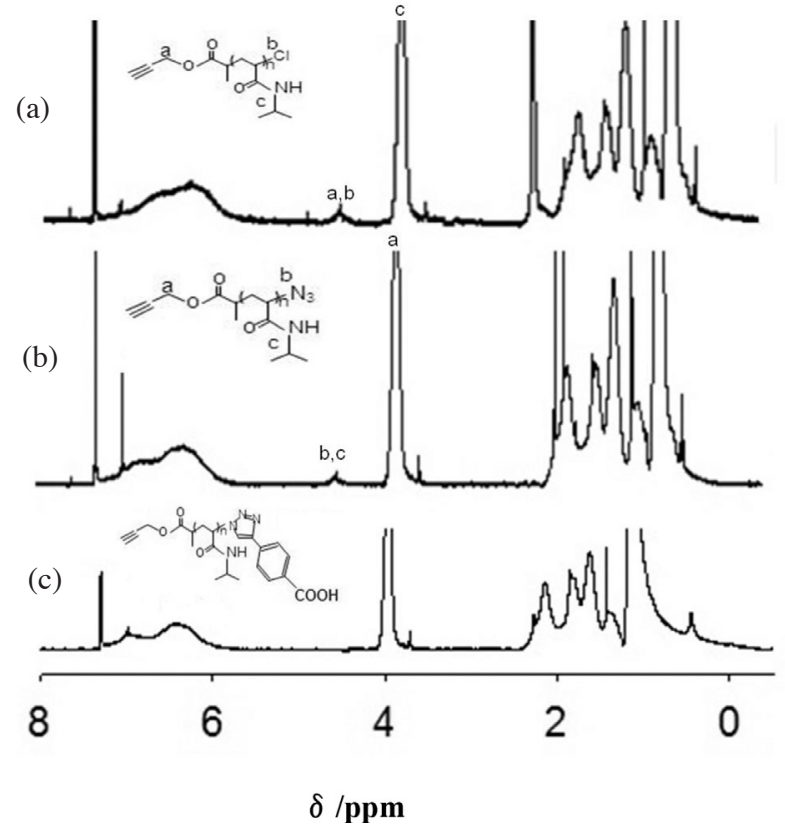

FIGURE 2. ${ }^{1} \mathrm{H}$ NMR spectra of (a) PNIPA- $\mathrm{Cl}$, (b)PNIPA- $N_{3}$, and (c) PNIPA-COOH in $\mathrm{CHCl}_{3}$

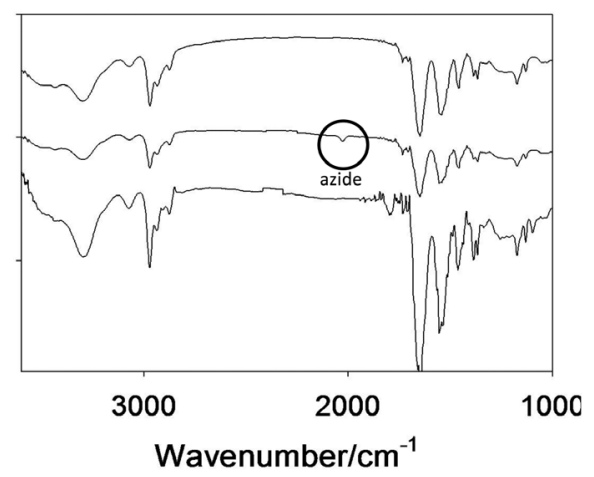

FIGURE 3. FT-IR spectra obtained for (a) PNIPA- $\mathrm{Cl}$, (b) PNIPA- $N_{3}$, and (c) PNIPA-COOH

\section{SYNTHESIS OF PNIPA-COOH}

PNIPA-N 3 (20.0 mg, $0.0655 \mathrm{mmol}$ ) and 4-ethanoic benzoic acid (173 mg, $1.31 \mathrm{mmol})$ were dissolved in dry DMF (0.3 $\mathrm{mL})$ and to this were added L-ascorbic acid $(23.1 \mathrm{mg}$, $0.131 \mathrm{mmol})$ in DMF $(0.131 \mathrm{~mL})$ and $\mathrm{CuSO}_{4} .5 \mathrm{H}_{2} \mathrm{O}(16.4$ $\mathrm{mg}, 0.0655 \mathrm{mmol})$ in DMF $(0.262 \mathrm{~mL})$, and the reaction mixture was stirred at ambient temperature. After $12 \mathrm{~h}$, L-ascorbic acid $(23.1 \mathrm{mg}, 0.131 \mathrm{mmol})$ in DMF $(0.131 \mathrm{~mL})$ and $\mathrm{CuSO}_{4} .5 \mathrm{H}_{2} \mathrm{O}(16.4 \mathrm{mg}, 0.0655 \mathrm{mmol})$ in DMF (0.262 $\mathrm{mL}$ ) were added again to the reaction mixture and the reaction mixture was again stirred at room temperature for $9 \mathrm{~h}$. The obtained polymer was then precipitated into a large amount of methanol and collected by centrifugation. The resulting polymer was dissolved in a small amount of DMF containing $\mathrm{LiCl}$ and the solution was poured into a large amount of hexane. This purification cycle was repeated three times. The obtained product was dried overnight in a vacuum dryer. (73\% yield). Complete conversion 
of PNIPA- $\mathrm{N}_{3}$ to PNIPA-COOH was confirmed by the FT-IR spectrum (Figure 3) which showed the disappearance of the azide signal of PNIPA-N $\mathrm{N}_{3}$. According to the ${ }^{1} \mathrm{H}-\mathrm{NMR}$ data of 4-ethanoic benzoic acid (Figure 4), proton peak for aromatic portion is appeared at $7.6 \mathrm{ppm} .{ }^{1} \mathrm{H}$ NMR data of purified PNIPA-COOH showed that the integration ratio of PNIPA-COOH at $7.6 \mathrm{ppm}$ position has increased which proves the presence of aromatic group at that position.

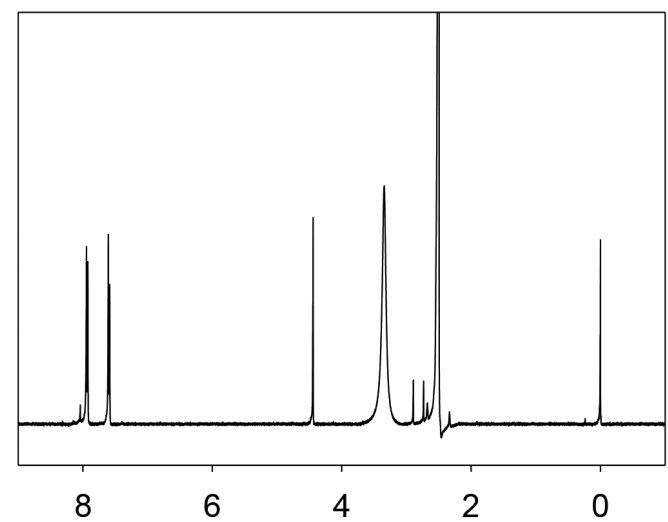

FIGURE 4. ${ }^{1} \mathrm{H}$ NMR data of 4-ethanoic benzoic acid

\section{SAMPLE PREPARATION}

ATRP technique has been used to synthesize homo polymer brushes to the surface tethering by grafting from method (Shah et al. 2000). PNIPA brush on silicon surface was synthesized by ATRP in the presence of a free initiator, $\mathrm{CuCl} / \mathrm{Me}_{6}{ }_{\mathrm{TREN}}$ system and DMF as a solvent. The covalent attachment of the initiator onto the silicon substrate was accomplished in a single step. The polymer brushes on silicon surface were synthesized by varying polymerization time from 0.5 to $8 \mathrm{~h}$ keeping the temperature constant at $20^{\circ} \mathrm{C}$. The end of this polymer chain is capped with an active halide atom that can be reinitiated to replace by other atoms. During polymerization monomer conversion and polymer molecular weight were determined at different stages. By GPC analysis number average molecular weight, $M_{n}$ and molecular weight distribution, $M_{w} M_{n}$ was obtained.

\section{RESULTS AND DISCUSSION}

The surface thermo-sensitivities of the PNIPA grafted membranes were determined by captive air bubble method. Measurement of contact angle using captive air bubble technique is a flexible technique in consideration of hydrophilicity/hydrophobicity of water attracting polymeric substrate. An air bubble was trapped underneath the polymer grafted membranes in water and equilibrated until the chemical potential of water vapor in the vaporsaturated air bubble equalized that of liquid water. Achieving an equilibrated contact angle of the air bubble took more than $30 \mathrm{~m}$ depending on the water temperature. Then the equilibrated contact of the air bubble was recorded after waiting an adequate amount of time. Figure 5(a) shows the static contact angle $\theta$, at different temperature for five different polymer brush samples with different chain length. Here, $\theta$ indicates the mean contact angle of $\theta$ 's at some separate locations on the respective sample. From the figure, we can see that the contact angle of all the grafted membranes slightly decrease with increasing temperature, where the decrement of $\theta$ is not observed while crossing the phase transition temperature. The contact angle suddenly starts to increase sharply at temperature $\sim 32^{\circ} \mathrm{C}$ and follows up to $40^{\circ} \mathrm{C}$ and then become constant. Although the net change of contact angle is not so large, but these surfaces show a remarkable temperaturedependant morphology change that shows very much unlike properties than conventional PNIPA gel surface. In case of conventional PNIPA gel, $\theta$ slightly decreases at low temperature and rapidly decreases at around LCST, followed by a slight decrease at higher temperature (Atsushi et al. 1999). Electro-negativity of terminally capped chloride molecule of PNIPA chain might be responsible for this different phenomenon of PNIPA-Cl grafted membrane than conventional PNIPA gel. As PNIPA brush is chemically stable, the change of wettability of the PNIPA brush surface occurs only by the exchange of water with surrounding environment and by the change of the terminal molecule of PNIPA membrane (Huda \& Kabir 2013). So the effects of the terminal atom of the PNIPA chain on the wettability should discuss to analyze the experimental results.

It is well known that the power of a chloride atom in a molecule to attract electrons to itself is higher than an azide molecule. So the electro-negativity of azide atom is lesser than that of chloride. So terminal chloride atom of PNIPA chain has been replaced by less electronegative azide $\left(-\mathrm{N}_{3}\right)$ group and the wettability has been measured. But in case of azide modified grafted film, hardly any difference was observed in the contact angle of the film (Figure 5(b)). The contact angle gradually decreased with increasing temperature up to $27^{\circ} \mathrm{C}$, and then while the temperature reached at LCST, the contact angle increase sharply as shown in previous PNIPA-Cl system. In case of PNIPA- $\mathrm{N}_{3}$, an increasing the contact angle after crossing the LCST, is not so steep comparing with PNIPA-Cl. Since the value of contact angle of the PNIPA- $\mathrm{N}_{3}$ grafted membrane has been reduced comparing to PNIPA-Cl system, it can be said that the modification of end group from chloride to azide reduce the hydrophilicity of the polymer surface. This phenomenon of grafted membrane shows that terminal molecule of PNIPA brush surface has an effect on the wettability of grafted film. Modification of chloride to azide group makes the surface more hydrophobic. But our concern mainly focused on the unexpected behavior of PNIPA grafted membrane at temperature near LCST. PNIPA-N $\mathrm{N}_{3}$ also shows similar types of trend with PNIPA-Cl at temperature near LCST. In order to find more significant effect of the terminal molecule, we modified the azide molecule of PNIPA chain to more hydrophobic carboxylic acid. When the carboxyl groups are attached to long alkyl chains, the hydrogen bonds are particularly stable. Hydrogen bonds between the acid and the anion are known to be much stronger than those between 
the unionized molecules. So carboxylic acid has more hydrophilic characteristics than those of chloride and azide molecule. Figure 5(c) shows the static contact angle of PNIPA-COOH grafted membrane at different temperature. Comparing with PNIPA-Cl and PNIPA-N ${ }_{3}$, the curves of all five PNIPA-COOH samples showed absolutely different trend near LCTS due to different surface properties. With increasing temperature, contact angle of the PNIPA-COOH grafted membrane decreases at low temperature, and rapidly decreases at around $31^{\circ} \mathrm{C}$, followed by a slight decrease at higher temperature. It should be noted that contact angle of the PNIPA-COOH rapidly but continuously changes at the transition temperature, which is opposite with the chloride and azide terminated grafted membrane. PNIPA-COOH has higher degree of freedom than PNIPA$\mathrm{Cl}$ and PNIPA-N $\mathrm{N}_{3}$, therefore it is easy for PNIPA-COOH to expand energy with increasing the temperature. This result of the contact angles of air bubble follows with the contact angle result of usually observed PNIPA gel. In case of PNIPA-COOH, the sessile air bubble accumulates the surface at the border of the contact at LCST, which might be a reason of decreasing the value contact angle.

\section{pH RESPONSIVE CONTACT ANGLE}

The contact angle of PNIPA brush was measured under the aqueous buffer solution with different $\mathrm{pH}$ values. Phosphate buffer with different $\mathrm{pH}$ strength was prepared. The concentration of the buffer solutions were kept constant at $0.01 \mathrm{~mol} \mathrm{~L}^{-1}$ and ionic strength of the solution was adjusted to $0.15 \mathrm{~mol} \mathrm{~L}^{-1}$ by the addition of $\mathrm{NaCl}$. The PNIPA-COOH modified substrate was immersed in the define buffer solution, kept it for $30 \mathrm{~min}$ to equilibrate and then measured the air bubble contact angle. The $\mathrm{pH}$ value was varied from 2 to 10 and back again from 10 to 2 . For each $\mathrm{pH}$ value, four spots were measured with the method for contact angle measurements as described above. Figure 6 shows the contact angle of PNIPA-COOH membrane as a function of the temperature under different $\mathrm{pH}$ solution. Here we see that the PNIPA-COOH grafted membranes also have phase transition under $\mathrm{pH}$ solution near the LCST of PNIPA. PNIPA-COOH chain conformation does not have any significant change at temperature region 10 to $28^{\circ} \mathrm{C}$, but the value of contact angle dropped rapidly while it crossed LCST of PNIPA. In this case, decrease of the contact angle may be ascribed to the decrease in the surface tension with the temperature rise. The value of contact angle for all samples become constant at temperature above $33^{\circ} \mathrm{C}$, which means that chain conformation of PNIPA-COOH does not have any change even at higher temperature. But at higher temperature, the grafted membrane become hydrophobic compared with lower temperature. From Figure 6, it is also clear that PNIPA-COOH brush membranes become hydrophilic with the increase of $\mathrm{pH}$ at all temperature.

Figure 7 shows equilibrium contact angles of air bubble resulting at $23^{\circ} \mathrm{C}$ underneath the PNIPA-COOH grafted membrane composed of molecular weight $\left(M_{n}\right)$ with 52000 and graft density of approximately 0.48 chain/
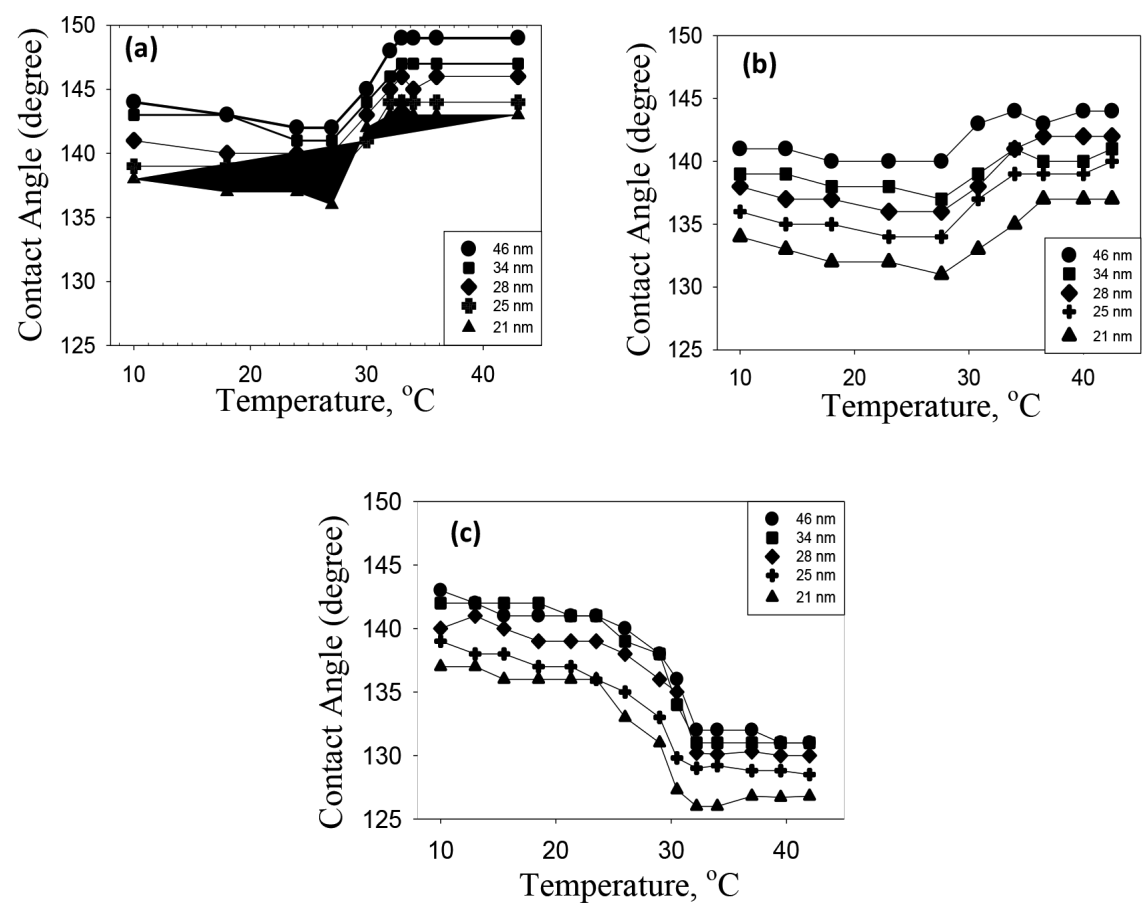

FIGURE 5. Contact angle of air bubble underneath PNIPA grafted membranes in water as a function of temperature,

(a) PNIPA- $\mathrm{Cl}$, (b) PNIPA- $\mathrm{N}_{3}$ and (c) PNIPA-COOH. Thickness (which were determined by AFM Nanopics imaging across the scratch boundary) of the five different samples are 46, 34, 28, 25 and $21 \mathrm{~nm}$ and the graft density of these samples are $0.48,0.5,0.46,0.5$ and 0.45 chain/ $\mathrm{nm} 2$, respectively 


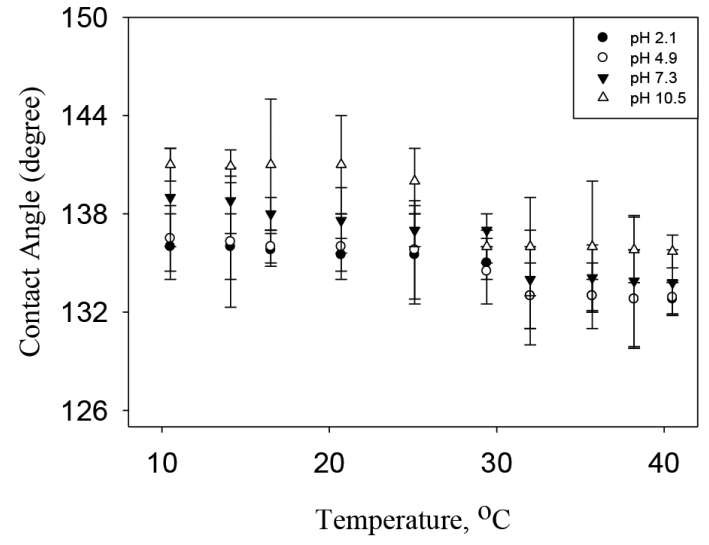

FIGURE 6. Contact angle of air bubble underneath PNIPA-COOH grafted membranes under different buffer solution as a function of temperature

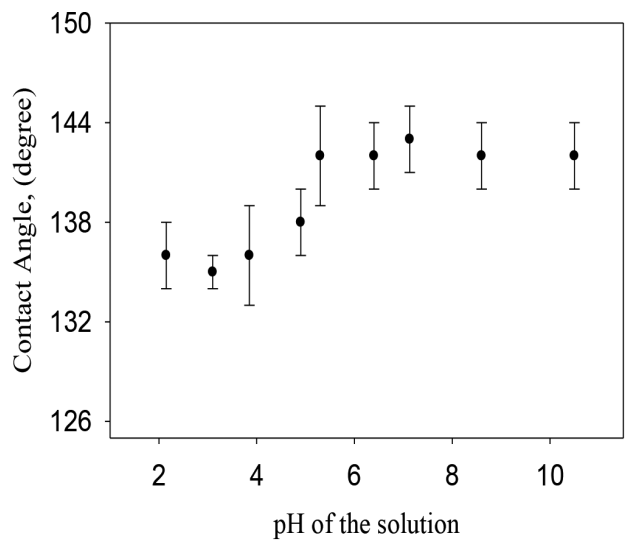

FIGURE 7. Contact angle of air bubble underneath PNIPA-COOH grafted membrane in buffer solution. Thickness of the polymer brush is $46 \mathrm{~nm}$ and graft density is 0.48 chain $/ \mathrm{nm}^{2}$

$\mathrm{nm}^{2}$. At $\mathrm{pH}$ levels lower than 4 , the value of contact angle was almost constant and almost independent of $\mathrm{pH}$. This might happen because some of the PNIPA-COOH molecules exist as un-ionized carboxyl groups at lower $\mathrm{pH}$, which form hydrogen-bonded complexes between amide and $-\mathrm{COOH}$ groups (Figure 8) (Irem et al. 2011). As the $\mathrm{pH}$ was increased at around 5, the value of contact angle was increased. This is because, with the increase of the $\mathrm{pH}$, the number of ionized carboxyl (carboxylate) groups on the network also increased, causing the grafted membrane hydrophilic. At higher $\mathrm{pH}$, the contact angle become constant meaning that PNIPA-COOH grafted membrane is also independent at higher $\mathrm{pH}$. Most of the carboxylate groups formed sodium salt combined with the sodium ion of the buffer solution. Therefore, it is clear that the contact angle of the grafted membrane depends on the charge density of carboxyl groups at buffer solution. At $\mathrm{pH}$ less than 5 , brush surfaces are less ionized resulted in the increase of positive charge on the brush surfaces, which caused the lower value of contact angle. At around $\mathrm{pK}_{\mathrm{a}}$ value of PNIPA-COOH, the inverse scenario may be assigned. Almost half of the carboxylate groups were ionized and the surface hydrophilic. The charges are completely compensated at higher $\mathrm{pH}$ (above 7) that resulted in a charge neutral and $\mathrm{pH}$ independent surface. Consequently, the contact angle becomes constant at the $\mathrm{pH}$ above 7 . This variation of hydrophobicity on the grafted membrane can only be understood in terms of the microenvironment of the monolayers, specifically the positions of the PNIPA chain with respect to the terminal ester groups of PNIPA-COOH chains.

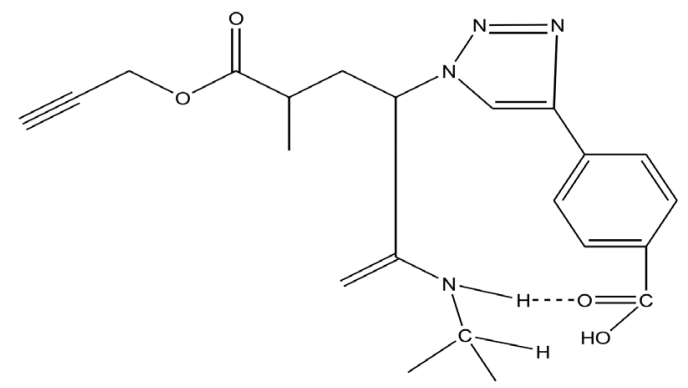

FIGURE 8 . Formation of a weak hydrogen bond between polymer chain at lower $\mathrm{pH}$

\section{CONCLUSION}

High density polymer brush on silicon substrate was synthesized successfully. In water, high density grafted membrane of PNIPA-Cl do not follow all properties of usually observed PNIPA gel. Surface roughness does not have any influence on the wettability of PNIPA-Cl grafted membrane. Terminal molecule of PNIPA-Cl chain can be positioned on the surface or can be hidden at the vicinity of the surface. Convertedof terminal molecule (chloride azide - $\mathrm{COOH}$ ) of PNIPA grafted chain reveals that the terminal moleculeof the PNIPA grafted chain can be positioned on the surface even at collapsed state.

\section{ACKNOWLEDGMENTS}

The authors gratefully acknowledged the financial support for scientific research from the Malaysia-Japan International Institute of Technology (MJIT), UTM Kuala Lumpur and Center for Advance Research in Sciences, University of Dhaka, Bangladesh.

\section{REFERENCES}

Abraham, M. 2004. Adhesion and wetting in an aqueous environment: Theoretical assessment of sensivity to the solid surface energy. Langmuir 20: 1317-1320.

Atsushi, S. \& Yasuhiro, K. 1999. Static contact angle of sessile air bubble on polymer gel surface in water. Jpn. J. Appl. Phys. 38: 2910-2916.

Cassie, A.B.D. \& Baxter, S. 1944. Wettability of porus surface. Trans Faraday Soc. 40: 546-551.

Chen, G. \& Hoffman, A.S. 1995. Graft copolymers that exhibit temperature-induced phase transitions over a wide range of pH. Nature (London) 373: 49-52. 
Grundke, K., Pöschel, K., Synytska, A., Frenzel, R., Drechsler, A., Nitschke, M., Cordeiro, A.L., Uhlmann, P. \& Welzel, P.B. 2015. Experimental studies of contact angle hysteresis phenomena on polymer surfaces - toward the understanding and control of wettability for different applications. Advances in Colloid and Interface Science 222: 350-376. DOI: doi: 10.1016/j.cis.2014.10.012.

Hiromasa, S., Huda, M.N., Hisashi, H., Kazushige, K.,Takahiro, S. \& Yukikazu, T. 2010. Precise synthesis and physicochemical properties of high-density polymer brushes designed with poly(N-isopropylacrylamide). Macromolecules 43: 99459956.

Huda, M. \& Kabir, A. 2013. Stimuli responsive morphological changes of Pnipa polymer brushes synthesized on silicon substrate. Journal of Molecular and Engineering Materials 2: $1-9$.

Irem, E., Helmut, S. \& Levent, D.A. 2011. Effect of structural isomerism and polymer end group on the $\mathrm{pH}$-stability of hydrogen-bonded multilayers. Journal of Colloid and Interface Science 361(2): 477-482.

Jin, L., Yin, Z. \& Zheng, L. 2014. Thermo-responsive brush copolymers with structure-tunable LCST and switchable surface wettability. Polymer 55: 6552-6560.

Kari, J.M. \& Yoram, C. 2014. Wettability of terminally anchored polymer brush layers on a polyamide surface. Colloid and Interface Science 436: 286-295.

Lamson, M., Maciej, K., Hangjun, D., Mingjiang, Z. \& Matyjaszewski, K. 2016. Synthesis of well-defined polyacrylonitrile by ICAR ATRP with low concentrations of catalyst. Polymer Chem . 54(13): 1961-1968. DOI: 10.1002/ pola. 28055 .

Manias, E., Rackaiti, M., Foley, T., Efimenko, K. \& Genzer, J. 2005. Combinatorial polymer brushes formed by temperature responsive polymers with tunable onset of response. Polymer Preprints 46(2): 11-12.

Pawel, K., Thomas, G.R., Matyjaszewski, K. \& Armando, G. 2016. Relation between overall rate of ATRP and rates of activation of dormant species. Macromolecules 49(7): 24672476. DOI: 10.1021/acs.macromol.6b00058.
Okano, T. 1993. Molecular design of temperature-responsive polymers as intelligent materials. Adv. Polym. Sci. 110: 179-197.

Prokhorova, S.A., Kopytsev, A., Ramakrishnan, H.Z.\& Rühe, J. 2003. Can polymer brushes induce motion of nano-objects? Nanotechnology 14: 1098-1103.

Shah, R.R., Merreceyes, D., Husemann, M., Rees, I., Abbott, N.L., Hawker, C.J. \& Hedrick, J.L. 2000. Using atom transfer radical polymerization to amplify monolayers of initiators patterned by micro contact printing into polymer brushes for pattern transfer. Macromolecules 33: 597-605.

Yamamoto, S., Ejaz, M., Tsujii, Y. \& Fukuda, T. 2000. Surface interaction forces of well- defined, high-density polymer brushes studied by atomic force microscopy. 2 . Effect of graft density. Macromolecules 33(15): 5608-5612.

Wenzel, R.N. 1936. Resistance of solid surfaces to wetting by water. Ind. Eng. Chem. 28: 988-994.

Nurul Huda* \& Nahida Sultana

Center for Advanced Research in Sciences

University of Dhaka, Dhaka 1000

Bangladesh

\section{Mohd. Rashid}

Malaysia-Japan International Institute of Technology

54100 UTM Kuala Lumpur, Federal Territory

Malaysian

*Corresponding author; email: write2shakil@gmail.com

Received: 6 April 2016

Accepted: 8 June 2016 